indeed, carbohydrate has come close to displacing ethanol from the position that that nutrient occupied in past years as the prime enemy of public well-being. Certainly that appreciable fraction of the population who look to women's magazines and other organs of the popular press for dietetic instruction might be excused for concluding that nutritional salvation was to be attained by the total extirpation of carbohydrate foods from their diets. The undesirable consequences, especially for the growing child, that may ensue if excessive carbohydrate in the diet crowds out, for example, protein are well recognized even if not fully understood. Nevertheless, it is perhaps permissible to question whether it can be taken for certain that wholesale reduction of carbohydrate intake by the average adult in this country would be physiologically advantageous. Certainly any such shift in the general pattern of consumption would have a catastrophic effect on our economy and even more on that of the primary producing areas overseas that live by selling us sugars and starches in various forms. Graham Lusk (1928) quotes Rubner as declaring that 'a large protein allowance is the right of civilized man' but world population pressures may before long make Chittenden's ( 1904 ) concept of protein economy more relevant.

The topics that our distinguished contributors are to discuss all touch in some degree on the problems that I have ventured to mention. If this Symposium serves to stimulate the interest of nutritionists in carbohydrate and to point the way for further investigation it will have served its purpose.

\title{
REFERENCES
}

Chittenden, R. H. (1904). Physiological Economy in Nutrition. New York: Frederick A. Stokes Co. Lusk, G. (1928). The Elements of the Science of Nutrition, $4^{\text {th }}$ ed. Philadelphia and London: W. B. Saunders Co.

Young, W. J. (1909). Proc. roy. Soc. B, 12, 528.

\section{Carbohydrates and protein}

By C. R. C. Heard, Human Nutrition Research Unit, National Institute for Medical Research, Mill Hill, London, $\mathrm{NW}_{7}$

\section{Introduction}

The invitation to contribute to this Symposium suggested that the title of my paper should be 'Carbohydrates and protein metabolism'. This, however, would have restricted discussion to a field which has already been reviewed by specialists, both in its biochemical (Munro, 1964) and nutritional (Miller \& Payne, 1964) aspects. Conversely a paper on 'Carbohydrate metabolism and protein' might have borne too close a resemblance to another paper (Blaxter, I964) given at last year's Symposium on the 'Interrelationships of Nutrients' ((The) Nutrition Society, I964). The whole point of that Symposium, in the present context, is that the utilization of dietary carbohydrate or protein is in every instance dependent on the other.

It would be impossible, and undesirable, in a review of this nature to cover the literature of such an enormous field. Instead an attempt will be made to underline 
some of the features of carbohydrate-protein interrelationships which are of importance to nutritionists and to examine the underlying principles which govern these relationships. The presentation will inevitably be coloured by my interest in the changes in carbohydrate metabolism brought about by protein-calorie deficiency.

Protein-calorie deficiency has until recently been thought of and investigated as if it were a disease affecting only protein metabolism. Diseases involving carbohydrate metabolism tend similarly to be segregated from those involving protein. Table I shows some of the principal clinical and biochemical signs of kwashiorkor, glycogen storage disease and diabetes, each of which is apt to be regarded as a disease involving disordered protein or carbohydrate metabolism. The striking similarity between many of the findings for these three conditions suggests that, like the synoptic gospels, they are all, if not of common authorship, at least describing the same events. They illustrate the point that neither protein nor carbohydrate metabolism can be affected without affecting the other.

Table I. Some clinical and biochemical signs of kwashiorkor, glycogen storage disease and diabetes

\begin{tabular}{|c|c|c|c|c|}
\hline \multicolumn{2}{|r|}{ Signs } & \multicolumn{2}{|r|}{$\begin{array}{l}\text { Glycogen } \\
\text { storaget }\end{array}$} & Diabetest \\
\hline Growth: & $\begin{array}{l}\text { stunted } \\
\text { adiposity } \\
\text { osteoporosis }\end{array}$ & $\begin{array}{l}+ \\
+ \\
+\end{array}$ & $\begin{array}{l}+ \\
+ \\
+\end{array}$ & $\begin{array}{l}+ \\
+ \\
+\end{array}$ \\
\hline Skin: & xanthoma & & + & + \\
\hline Liver: & $\begin{array}{l}\text { fat accumulation } \\
\text { glycogen 'storage' } \\
\text { glucose-6-phosphatase }\end{array}$ & $\begin{array}{c}+ \\
+ \\
\text { Low }\end{array}$ & $\begin{array}{c}+ \\
+ \\
\text { Low } \\
\text { (type I) }\end{array}$ & $\begin{array}{c}+ \\
+ \\
\text { High }\end{array}$ \\
\hline Blood: & $\begin{array}{l}\text { glucose } \\
\text { pyruvate, lactate } \\
\text { lipids }\end{array}$ & $\begin{array}{r}\text { Low } \\
\text { High } \\
\rightarrow \text { High }\end{array}$ & $\begin{array}{l}\text { Low } \\
\text { High } \\
\text { High }\end{array}$ & $\begin{array}{r}\text { High } \\
\rightarrow \text { High } \\
\text { High }\end{array}$ \\
\hline Urine: & $\begin{array}{l}\text { glucose } \\
\text { ketones }\end{array}$ & - & $\bar{t}$ & $t$ \\
\hline $\begin{array}{l}\text { Glucose } t \\
\text { Tendency }\end{array}$ & $\begin{array}{l}\text { tolerance } \\
\text { y to infections }\end{array}$ & $\begin{array}{c}\text { Impaired } \\
\text { High }\end{array}$ & $\begin{array}{l}\text { Impaired } \\
\text { High }\end{array}$ & $\begin{array}{c}\text { Impaired } \\
\text { High }\end{array}$ \\
\hline
\end{tabular}

\section{Effects of dietary carbohydrates on protein metabolism}

The two actions of carbohydrate on protein metabolism. Dietary carbohydrate has been shown to have two distinct, if not separate, actions on protein metabolism. The first of these it shares with other energy-yielding nutrients such as fat or alcohol. In this role carbohydrate prevents the misuse of dietary protein for meeting calorie requirements. Carbohydrate also regulates protein metabolism through the specific effect of blood glucose on the endocrine glands. 
The evidence for these two actions of carbohydrate on protein metabolism has been fully documented and discussed by Munro (1964). To distinguish between them it is proposed to refer to the 'carbohydrate-energy effect' and the 'carbohydrateendocrine effect'. The latter term is preferred to Munro's 'carbohydrate-insulin' because of its broader implications.

The carbohydrate-energy effect on protein metabolism. 'This protein-sparing action is not specific for carbohydrate. It is governed by the fact that at an adequate level of protein intake, nitrogen balance is positively correlated with total calorie intake. Increasing calorie intake is, however, much less effective in a situation in which nitrogen balance is limited by an inadequate supply of dietary protein; and increasing the protein intake is similarly ineffective when dietary calories are limited (Munro, I951; 1964; Calloway \& Spector, I 954).

In the sphere of practical nutrition, these concepts have found their application in the development of methods for expressing the protein values of diets, which take account not only of the quantity and quality of dietary protein but also of the calorie intake. This has led to much more precise definition of the protein values of human diets and regimens and has enabled these values to be compared directly with similarly expressed values for protein requirements (Platt, Miller \& Payne, i 96I). It has also ensured more meaningful control of diets used for experimental animals.

The carbohydrate-endocrine effect on protein metabolism. In addition to the proteinsparing action of carbohydrate outlined above, dietary carbohydrate has a specific effect on protein metabolism not shared with fat. This has been revealed by shortterm experiments with animals, or in man, in which the isocaloric replacement of dietary carbohydrate by fat has led to a decrease in nitrogen balance (see Munro, 1964). This effect has been observed also in experiments on the effects of shock on nitrogen balance, again both experimentally and in human subjects suffering accidental or surgical trauma (Cuthbertson, r960; Kinney, 1962). Also in the treatment of obesity, loss of weight has been reported to be less with diets containing a high proportion of carbohydrate than with isocaloric high-fat diets.

The most feasible explanation for this specific effect of carbohydrate on protein metabolism lies in the link provided by the endocrine glands between carbohydrates and protein metabolism. Munro (1964) has suggested that insulin secretion and activity is of paramount importance. The increase in plasma insulin activity stimulated by elevated blood glucose levels would be expected to promote the uptake of glucose but also, and independently, the uptake of amino acids by peripheral tissue (Manchester \& Young, 1958, 1960).

Quite clearly this may be an oversimplification, but it points in the right direction. Hormones other than insulin are likely to be involved and the effects of carbohydrate will depend on the age, sex and physiological state of the animal.

Insulin and growth hormone have synergistic effects on growth (Manchester \& Young, 1961) and the secretion of both is related to blood glucose levels (Roth, Glick, Yalow \& Berson, 1963); so also is the release of glucagon from the $\alpha$-cells of the islets of Langerhans (Unger, Eisentraut \& Madison, 1963). The development of specific immunological methods for the assay of insulin, growth hormone and 
glucagon has opened the way to an investigation of the secretion of these hormones in response to the withdrawal or supply of food.

Janz, Doorenbos \& Reitsma (I963) showed that serum growth hormone levels are raised by fasting and lowered by food, and in particular by carbohydrate rather than protein or fat. This interrelationship between carbohydrate and growth hormone was clarified by Roth et al. (1963) who demonstrated that, in normal human subjects, hypoglycaemia produces an immediate and sustained rise in the levels of growth hormone in plasma. The effect is dependent on blood glucose concentration and not on insulin, glucagon or adrenaline.

These recent investigations have also made it clear that growth hormone as measured both in serum and in pituitary extracts is present in adults (including the elderly) at levels not appreciably less than those found in children (Janz et al. 1963). It still has a metabolic function even when body growth is completed. Moreover, it is probable that growth restriction, whether because of age or dietary inadequacies in the young, may, under certain circumstances, lead to growth hormone assuming exaggerated importance in the regulation of carbohydrate metabolism.

Rabinowitz \& Zierler ( 1963 ) believe that recent findings in regard to the secretion of insulin and growth hormone after meals reveal the presence of a 'metabolic regulating device' which operates as follows. A meal containing adequate supplies of carbohydrate and protein stimulates insulin release and diminishes the secretion of growth hormone. During this absorptive phase the peripheral uptake of glucose is preferentially stimulated. In the immediate postabsorptive phase, when the concentration of insulin is still elevated, growth hormone secretion is also increased and, in the presence of insulin, stimulates amino acid uptake into, and protein synthesis in, cells well supplied with carbohydrate. To this may be added the observation that, in the later postabsorptive phase, with the initiation of fasting, diminishing insulin and rising growth hormone levels inhibit the uptake of glucose by muscle and conserve the extracellular glucose pool for the metabolic requirements of the nervous tissue (which is not dependent on insulin). At the same time high growth-hormone-low insulin concentrations favour lipolysis and the release of non-esterified fatty acids (NEFA) as sources of energy for peripheral tissue. Rising NEFA levels will also inhibit the uptake of glucose by muscle, and may indeed be the immediate cause of the hormonal inhibition of glucose uptake (Randle, Garland, Hales \& Newsholme, 1963).

These recent findings, in regard to changes in hormonal concentrations in relation to blood glucose levels, explain why the specific action of glucose on protein metabolism is observed only when carbohydrate and protein are eaten in the same meal (Munro, 1964). Furthermore, the timing of the meals themselves has been shown to be of considerable importance in the utilization of food (Cohn \& Joseph, I960; Gwinup, Byron, Roush, Kruger \& Hamwi, I963).

Does the type of carbohydrate matter? On the basis of the two actions of carbohydrate outlined above, it would be expected that under normal nutritional conditions the effect of various classes of dietary carbohydrate would be decided by (I) rate of digestion, if a polysaccharide; (2) rate of absorption; (3) rate of rise of blood 
glucose; (4) responsiveness of endocrine glands. A predominantly starchy diet, from which glucose is released relatively slowly into the blood stream, would be expected to have effects rather different from a diet containing a high proportion of rapidly available glucose, whether in the free form or as sucrose. When diets are offered $a d l i b$., carbohydrates such as starch and sucrose may differ in their effectiveness in promoting nitrogen retention, but this may be due to factors affecting the regulation of food intake (Yoshida, Harper \& Elvehjem, 1958).

Cohen \& Teitelbaum (1964) have reported that diets with a high proportion of sucrose, whether supplied to human subjects or rats, lead to impaired glucose tolerance and other diabetic lesions, owing to over-stimulation and exhaustion of the $\beta$-cells. Clearly such changes would also influence nitrogen balance.

Whether an effect of variation in type of carbohydrate on protein metabolism could be detected or not would depend on the relative magnitude of the carbohydrateenergy and carbohydrate-endocrine effects. In the rat, in which the latter effects are relatively smaller than in man (Munro, 1964), a difference in endocrine effect on nitrogen balance as between starch and glucose may be difficult to demonstrate.

My colleague, Mr M. R. Turner (1964, personal communication), has found differences in glucose tolerance between rats fed on high- or on low-protein diets,

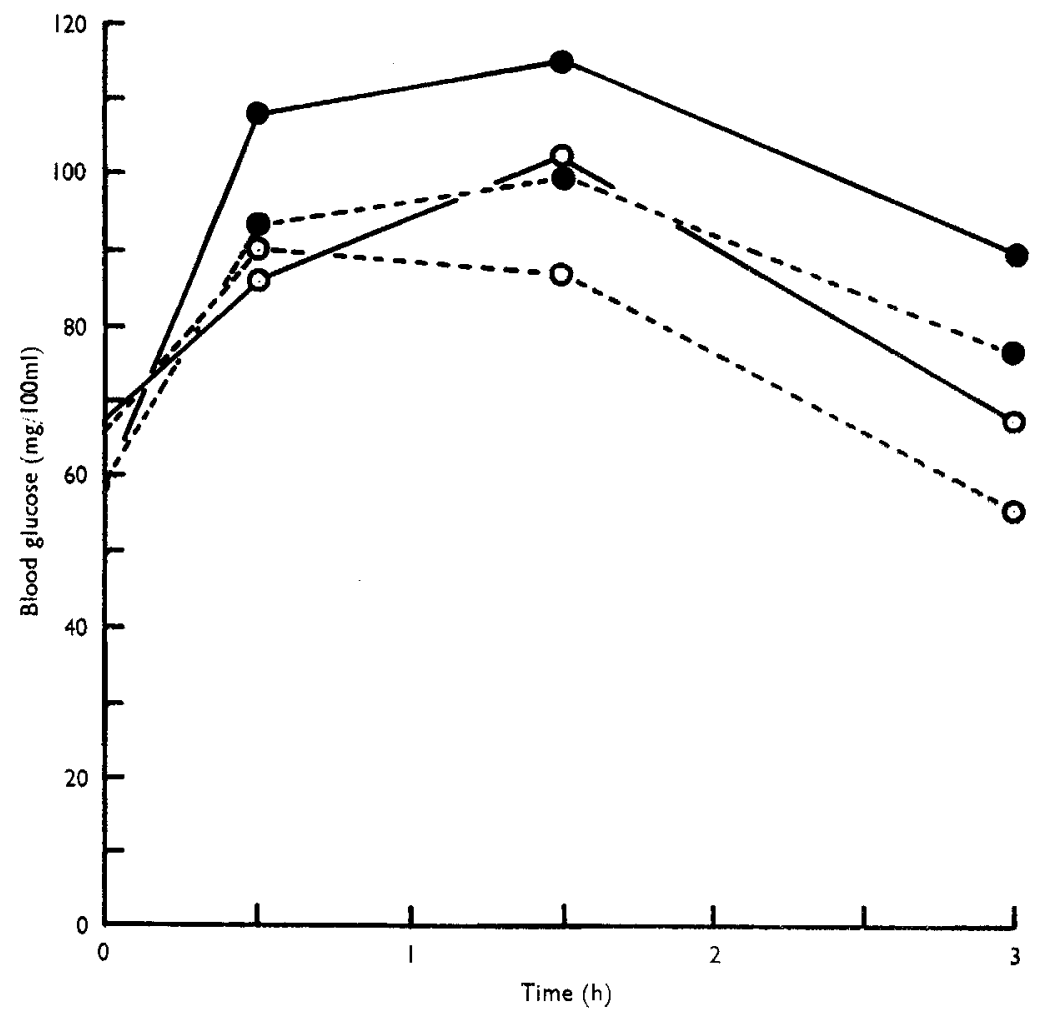

Fig. I. Glucose tolerance of rats fed on high- (HP) or low- (LP) protein diets with carbohydrate supplied principally as starch or sucrose (NDpCal \% of diets: $\mathrm{HP}=10 \cdot 2 ; \mathrm{LP}=5 . \mathrm{I}$ ). (M. R. Turner, I964, personal communication.) -O, HP-starch; O-O, HP-sucrose; --- , $^{-}$ LP - starch; $0---0, \mathbf{L P}-$ sucrose. 
containing either a high or a low proportion of sucrose (Fig. I). Glucose tolerance in this instance serves as an indicator of changes in endocrine status induced by variations in amount of dietary protein and type of dietary carbohydrate. If these results are consistent with a carbohydrate-endocrine action they equally suggest a protein-endocrine action. 'This leads us to consider a further question.

Does the protein value of the diet modify the action of the carbohydrate? This question has already been partly answered above, where it was pointed out that the carbohydrate-energy action appears to be effective only under conditions in which dietary protein is not the limiting factor. That this is not the whole truth is shown by a comparison of urinary nitrogen excretion of fasting subjects (Cathcart, 1907) with that of subjects consuming a diet almost devoid of protein but supplying i $800 \mathrm{kcal} /$ day (Folin, I905). When calorie requirements are satisfied urea excretion is much reduced. Presumably the carbohydrate is in this instance exerting a protein-sparing action on the body's tissue proteins. From this it might be argued that in subjects suffering from protein-calorie deficiency, a high-carbohydrate, low-protein diet is preferable to one deficient in both carbohydrate and protein.

Effects of carbohydrate supplementation of diets of low protein value. Pigs maintained on restricted amounts of a diet of low protein value also showed a reduction in urinary urea nitrogen excretion when extra carbohydrate was given (Heard, Platt 8 Stewart, 1958). However, in these animals the diminished excretion of urea was due to impaired absorption of nitrogen - one of the many signs of protein-calorie deficiency which are exaggerated by continued ingestion of extra carbohydrate (Platt, Heard \& Stewart, $1964 b$ ). This 'protein-wasting' effect of carbohydrate has been fully reported elsewhere (Platt \& Stewart, 1962; Platt et al. 1964a).

Since it has been shown for animals of very different sizes, whether in positive or negative nitrogen balance, that the protein-sparing action of carbohydrate amounts to $6 \mathrm{mg} \mathrm{N} / \mathrm{kcal}$ (Miller \& Payne, I963), a protein-wasting effect of carbohydrate must be due to diversion of either the source of energy or the source of nitrogen. Young pigs kept at constant weight, on diets of low protein value, retain their ability to dispose of considerable quantities of 'excess' carbohydrate (Miller \& Payne, I 962). The enzymes linking carbohydrate metabolism with protein synthesis are themselves proteins which require renewal. Possibly a continued carbohydrate load imposes a demand for these enzymes which the protein-deficient system is unable to meet. Similar considerations apply to hormones (other than those of the adrenal), and there are strong indications that the protein-wasting effect of carbohydrate is due to changes in carbohydrate-endocrine rather than carbohydrate-energy action.

Since glucose, as such, has an important role in the regulation of protein metabolism, it is significant that alterations in the homoeostatic control of blood glucose levels are characteristic of protein-calorie deficiency and differ according to the degree of deficiency. In severe protein-calorie deficiency there develops an insufficiency of insulin and of thyroid and growth hormones, coupled with a relative excess of adrenocortical hormones (Platt et al. 1964a). The effect of this altered endocrine balance would be to increase loss of nitrogen from the body as a whole, because of the mobilization of peripheral tissue protein (muscle and bone) to supply amino 
acids for more essential organs or structures. In its simplest form this may be viewed as a response to stress, and the role of the adrenal in homoeostasis in protein-deficient animals has been firmly established (Aschkenasy, I96I).

Although the endocrine changes, summarized above, may in the first instance be adaptive, they cannot protect indefinitely against the effects of diets of inadequate protein value. Their protective effect is even more short-lived if the diet is relatively rich in carbohydrate, probably because this accelerates exhaustion of the $\beta$-cells and, apart from any biochemical effect, by satisfying hunger, delays exhaustion of the adrenals. This effect accentuates the insulin-glucocorticoid imbalance which, in turn, would intensify the diversion of amino acids away from muscle; it would also inhibit still further the assimilation of glucose from plasma and thus impose, or increase, calorie restriction at the cellular level, as in diabetes.

\section{Effects of protein-calorie deficiency on carbohydrate metabolism}

Protein-calorie deficiency may result from one or more of the following: diets of inadequate protein value; infection; shock, surgical trauma; diseases of less clearly defined aetiology, in which the digestion, absorption, utilization or excretion of proteins or amino acids is abnormal (e.g. malabsorption syndromes, pancreatic (exocrine or endocrine) diseases, liver diseases, protein-losing enteropathies, renal diseases).

Changes in carbohydrate metabolism observed in young pigs fed on diets of very low protein value include: impaired digestion and absorption of carbohydrate, decreased tolerance to intravenous glucose, excessive accumulation of glycogen in the liver, decrease in availability of this glycogen to correct hypoglycaemia following intravenous insulin. These changes form part of the characteristic picture of severe protein-calorie deficiency in animals and man (Platt et al. 1964a; Heard, 1964, in preparation) and reflect changes in the endocrine glands summarized above.

Similar studies have been made on dogs reared on diets which, though of much higher protein value than those given to the pigs, were still suboptimal for growth, pregnancy and lactation. Superficially the changes in carbohydrate metabolism were very similar in the mildly protein-calorie deficient dogs and the severely deficient pigs. A notable exception was the response to intravenous insulin. Mild proteincalorie deficiency resulted in increased insulin resistance, and severe deficiency in insulin sensitivity. The insulin resistance of the dogs was associated with elevated levels of insulin-like activity, effective in stimulating glucose uptake by adipose tissue but not by muscle (Turner, i 962 ; Heard, Turner \& Platt, I964). The effect of these changes in levels of circulating insulin, and probably also of growth hormone, on protein metabolism has not been studied, but their effect on carbohydrate metabolism is to simulate a condition closely resembling that found in adult-onset diabetes and obesity (Heard \& Platt, 1964).

It is well recognized that diabetes mellitus may be precipitated by infection; the same claim has been made for kwashiorkor. In many respects the chemical pathology and morbid anatomy of infection are the same as those of protein-calorie deficiency 
and are most marked in animals fed on diets of low protein value (Platt $e t$ al. $1964 b$ ). Carbohydrate metabolism is not likely to prove an exception to this rule but may also be modified by endocrine reactions to the stress of infection, or by toxic products of the infective agent or process. Although we have not yet made a systematic study of this problem, preliminary results obtained with dogs infected with Toxocara canis (Al-Rabii, 1963 ) indicate that increasing the severity of infestation leads to impairment of glucose tolerance and, conversely, deworming to improved tolerance.

\section{Possible links between 'carbohydrate-energy' and 'carbohydrate-endocrine' actions on metabolism}

The fact that diseases of protein or carbohydrate metabolism have much in common may merely be a reflection of what some members of our Unit call the 'unwell syndrome'. On the other hand, there are real biochemical grounds for expecting protein and carbohydrate metabolism to be linked in at least two ways-firstly through common metabolic paths such as the Krebs cycle, and secondly through their effect on, and the way they are affected by, endocrine status. The first of these links is probably the more fundamental or primitive. Indeed, my first conscious introduction to this field was Chibnall's ( 1939 ) account of the role of carbohydrate in plant protein metabolism.

One would expect the evolution of the nervous system, mobility and intermittent feeding habits to be accompanied by the development of control mechanisms, permitting modification of metabolism to suit fairly rapidly changing requirements. One such mechanism, mediated through blood glucose levels and endocrine secretions, has been outlined above.

Randle et al. (1963) have proposed a possible link between the metabolic and endocrine control of carbohydrate metabolism in the 'glucose fatty-acid cycle'. This 'provides a primitive mechanism which quite independently of hormonal control will tend to maintain a constant plasma glucose concentration in animals that feed intermittently'. The essence of this mechanism is that the uptake of glucose by muscle is inhibited by NEFA, whereas in adipose tissue the release of NEFA from triglycerides is inhibited by glucose uptake. Control of the cycle is modified by (a) insulin which enhances glucose uptake by muscle and adipose tissue and inhibits release of fatty acids in adipose tissue and (b) growth hormone, corticosteroids and adrenaline which accelerate release of fatty acids from adipose tissue and muscle, and may, by this action (i.e. elevated NEFA levels), inhibit uptake of glucose by muscle at a particular insulin concentration.

Common biochemical signs are found in the 'unwell syndrome' which includes diabetes, starvation, carbohydrate deprivation, excess of growth hormone or corticosteroids and perhaps obesity. Many abnormalities in carbohydrate metabolism in these diseases are attributable to a high plasma concentration of NEFA, arising from the breakdown of glycerides in adipose tissue and muscle and Randle et al. (1963) believe that these common biochemical signs represent a distinct syndrome--the 'fatty-acid syndrome'. 
We have therefore (a) carbohydrate-protein interactions based on metabolic interrelationships susceptible to endocrine control, and (b) carbohydrate-fat interactions based on the glucose-fatty acid cycle, control of which is also modified by hormones. Quite clearly, the final picture of carbohydrate-protein interrelationships must include fat metabolism. For example, it is probably no mere coincidence that serum levels of polyunsaturated fatty acids are altered both in diabetes (Cornwell, Kruger, Hamwi \& Brown, 1962) and in kwashiorkor (Naismith, 1964) as well as in 'pure' deficiency of essential fatty-acids.

Most of us have only limited vision of our own particular field, and it may well have to be left to a computer to integrate our isolated fragments of knowledge. We can, however, expect increasingly elegant confirmation of St Paul's statement that 'God hath tempered the body together... that there should be no schism in the body; but that the members should have the same care one for another. And whether one member suffer, all the members suffer with it, or one member be honoured, all the members rejoice with it' (1 Cor. I2, 24-26).

\section{REFERENCES}

Al-Rabii, H. A. (1963). The effect of dietary protein levels upon host and parasite in dogs infected with Toxocara canis. Ph.D. Thesis, University of London.

Aschkenasy, A. (196r). Ann. Nutr., Paris, 15, B 165.

Blaxter, K. L. (1964). Proc. Nutr. Soc. 23, 3.

Calloway, D. H. \& Spector, H. (1954). Amer. F. clin. Nutr. 2, 405.

Cathcart, E. P. (1907). Biochem. Z. 6, 109.

Chibnall, A. C. (1939). Protein Metabolism in the Plant. Oxford: University Press.

Cohen, A. M. \& Teitelbaum, A. (1964). Amer. F. Physiol. 206, 105.

Cohn, C. \& Joseph, D. (1 960). Metabolism, 9, 492.

Cornwell, D. G., Kruger, F. A., Hamwi, G. J. \& Brown, J. B. (1962). Metabolism, I1, 840.

Cuthbertson, D. P. (1960). In The Biochemical Response to Injury, p. I93. [H. B. C. Stoner and C. J. Threlfall, editors.] Oxford: Blackwcll.

Folin, O. (1905). Amer. 7. Physiol. 13, 66.

Gwinup, G., Byron, R. C., Roush, W., Kruger, F. \& Hamwi, G. J. (r963). Lancet, ii, i65.

Heard, C. R. C. \& Platt, B. S. (1964). In Melabolism and Physiological Significance of Lipids. [R. M. C. Dawson, cditor.] I ondon: John Wiley and Sons I.td.

Heard, C. R. C., Platt, B. S. \& Stewart, R. J. C. (1958). Proc. Nutr. Soc. 17, xli.

Heard, C. R. C., 'Turner, M. R. \& Platt, B. S. (1964). Proc. Nutr. Soc. 23 , vi.

Janz, A., Doorenbos, H. \& Reitsma, W. D. (1963). Lancet, i, 250.

Kinney, J. M. (1962). In Protein Metabolism: an International Symposium, p. 275. [F. Gross, editor.] Berlin: Springer.

Manchester, K. L. \& Young, F. G. (1958), Biochem. 7. 7o, 353.

Manchester, K. L. \& Young, F. G. (1960). In The Mechanism of Action of Insulin, p. 1 13. 1F. G. Young, W. A. Brom and I: W. Wolff, editors.] Oxford: Blackwell.

Manchester, K. L. \& Young, F. G. (r96I). Vitam. \& Horm. r9, 95.

Miller, D. S. \& Payne, P. R. (rg62). F. Nutr. 78, 255.

Miller, D. S. \& Payne, P. R. (1963). F. theoret. Biol. 5, 260.

Miller, D. S. \& Payne, P. R. (I964). Proc. Nutr. Soc. 23, I1.

Munro, H. N. (I95I). Physiol. Rev. 3I, 449.

Munro, H. N. (1964). In Mammalian Protein Metabolism. Vol. x, p. 38 I. [H. N. Munro and J. B. Allison, editors.] New York: Academic Press Inc.

Naismith, D. J. (1964). Proc. Nutr. Soc. 23, viii.

Nutrition Society (1964). Proc. Nutr. Soc. 23, I-53.

Platt, B. S., Heard, C. R. C. \& Stewart, R. J. C. (1964a). In Mammalian Protein Metabolism. Vol. 2, p. 445. [H. N. Munro and I. B. Allison, editors.] New York: Academic Press Inc.

Platt, B. S., Heard, C. R. C. \& Stewart, R. J. C. (1964b). In The Role of the Gastro-intestinal Tract in Protein Metabolism, p. 227. Symposium of C.I.O.M.S. [H. N. Munro, editor.] Oxford: Blackwell. 
Platt, B. S., Miller, D. S. \& Payne, P. R. (196r). In Recent Advances in Human Nutrition, p. 35 I. [J. F. Brock, editor.] London: J. \& A. Churchill.

Platt, B. S. \& Stewart, R. J. C. (1962). Brit. F. Nutr. 16, 483.

Rabinowitz, D. \& Zierler, K. L. (1963). Nature, Lond., r99, 913.

Randle, P. J., Garland, P. B., Hales, C. N. \& Newsholme, E. A. (1963). Lancet, i, 785.

Roth, J., Glick, S. M., Yalow, R. S. \& Berson, S. A. (1963). Science, I4o, 987.

Turner, M. R. (1962). The effects of state of nutrition and pregnancy on glucose tolerance in experimental animals. M.Sc. Thesis, University of London.

Unger, R. H., Eisentraut, A. M. \& Madison, L. L. ( 1963$)$. F. clin. Invest. 42, 103 I.

van Creveld, S. (1963). Canad. med. Ass. F. 88, I.

Williams, R. H. (editor). (1960). Diabetes. New York: Hoeber.

Yoshida, A., Harper, A. E. \& Elvehjem, C. A. (1958). F. Nutr. 66, 217.

\section{Dietary carbohydrates and lipid metabolism}

\section{By I. Macdonald, Physiology Department, Guy's Hospital Medical School, London, $S E$ I}

The role of dietary carbohydrate in lipid metabolism has been known for some time, and this knowledge forms the basis of many agricultural practices. The conversion of carbohydrate into fat is also accepted in man and forms the mainstay of some therapeutic manoeuvres. Despite the widespread acceptance of a metabolic relationship between carbohydrate and lipid, there has been little critical analysis of this relationship. The dietary carbohydrates have been assumed to be bland constituents, all treated alike as a result of the activities of the gut and consequently, until recently, few suggestions have been made that would implicate them in disorders of lipid metabolism.

Some evidence that dietary carbohydrate may play a significant part in disease was seen in the study of kwashiorkor. The child with this malnutritional disorder not only shows the signs of protein deficiency but in addition has pathological changes which can only be due to a relative dietary excess of calories over protein, and the calories are usually supplied by carbohydrate. The large quantity of fat in the liver and the presence of reasonable quantities of depot fat mark out this malnutritional disorder from marasmus in which the child not only has a deficient protein intake but also has a similarly deficient calorie intake, the marasmic child being wasted, with no depot fat or excess liver lipid. The remarkably low serum albumin levels in kwashiorkor led to the belief that deficiency of protein was the principal dietary fault, but some experimental work in man has shown that even on a high protein intake the serum albumin is reduced by a high carbohydrate intake (Coles \& Macdonald, 1964, in preparation). Thus, calories in the form of carbohydrate may have a malevolent effect in these children. It is of interest to speculate whether it is the carbohydrate or the calories that result in the changes characteristic of kwashiorkor and therefore whether calories in the form of fat would also result in the same clinical picture.

\section{Experiments on animals}

In an attempt to understand the effects of dietary carbohydrates on lipid metabolism, rabbits were placed on diets so arranged that the protein intake was kept constant but the carbohydrate (and thereby the calorie) intake varied. The results 